\title{
Integrated Development of Health Tourism Under the Background of Rural Revitalization Strategy
}

\author{
Dai Xingme $^{1 *}$ \\ ${ }^{1}$ Beihai Secondary Vocational and Technical School, Beihai, Guangxi , China \\ *Corresponding Author.
}

\begin{abstract}
:
This paper studies the integrated development of forest health tourism under the background of Rural Revitalization Strategy. Based on the tourism destination life cycle theory, tourism destination competitiveness theory and experience economy theory, this paper uses the linear function weighting method to establish a measurable evaluation standard of forest health development potential. This paper constructs the evaluation index system of forest health tourism development potential through Delphi method, determines the index weight combined with analytic hierarchy process, and establishes a practical comprehensive scoring model and evaluation grade. This paper uses the fuzzy comprehensive evaluation method to evaluate the development potential of forest health tourism in three forest health bases: DWS National Forest Park, FJS National Nature Reserve and LYS National Forest Park.
\end{abstract}

Keywords: Rural Tourism, Forest, Health Tourism, Integrated Development

\section{INTRODUCTION}

Human sub-health is a "wandering state" between health and disease. If this state can not be corrected in time, it will easily lead to physical and mental diseases. According to the data released by the China International Symposium on academic achievements in sub-health, about $70 \%$ of China's people are in a state of sub-health [1-2]. The reasons for this state mostly come from problems such as high living pressure, serious air pollution, deterioration of urban living environment and so on. Forest is one of the most suitable places for human beings to live. It can better meet the needs of people to improve their quality of life [3-4]. The forest with excellent ecological environment has been paid more and more attention by the medical community. As a non-traditional medical physiotherapy, forest health care is widely used in people's daily life. It is an excellent integration of forest environment and medical treatment [5]. 
Article History: Received: 28 October 2021 Revised: 05 December 2021 Accepted: 10 January 2022 Publication: 28 February 2022

Forest health tourism is the hot spot of modern tourism development [6]. At present, China's forest health tourism is in the initial development stage, although it has been paid attention by the majority of scholars. However, the relevant research still lags behind the development of reality. Most of the research results draw on the established achievements of foreign countries. The research in theory and practice is very scarce, which is difficult to meet the development requirements of forest tourism resources in China at the present stage [7-10]. Therefore, this study takes forest health tourism as the research object, establishes an evaluation index system, and comprehensively evaluates the development potential of forest health tourism in Daweishan National Forest Park, Fanjingshan National Nature Reserve and Langyashan National Forest Park with fuzzy quantitative evaluation method. It can not only provide evaluation criteria for domestic forest health tourism, but also promote the sustainable development of forest health tourism.

\section{CONSTRUCTION OF EVALUATION INDEX SYSTEM OF FOREST HEALTH TOURISM DEVELOPMENT POTENTIAL}

Construction principles of evaluation index system:

(1) feasibility principle. The selection of evaluation indicators should not only consider the availability of index data, but also consider its monitoring and operability, and comprehensively consider whether it has the value of popularization and practical use. In the evaluation index system of forest health tourism development potential, the quantitative index data are from official statistics and forest health base data, and the qualitative index data are from tourist questionnaires.

(2) Comprehensive and systematic principle. The construction of forest health tourism development potential index system must focus on the sustainable development of ecological and environmental quality of the base, and comprehensively consider the internal factors such as resource endowment conditions, environmental quality, infrastructure and service facilities of the base. External factors such as external development conditions and the attitude of local stakeholders (such as the government and local residents) also need to be considered. Various indicators need to be hierarchical and non overlapping, and can reflect the structure, function and benefits of the system in an all-round, multi angle and deep level.

(3) Dynamic principle the external natural environment, economic and market conditions on which the development of forest health tourism depends are constantly changing and developing. Therefore, the development status and future development trend of the base should be evaluated from the perspective of dynamic development. In the evaluation, the economic data of recent three years are used to calculate the annual income growth rate and tourist growth rate of the base, so as to provide basis for the rational layout and planning of forest health tourism development in the base. 
Article History: Received: 28 October 2021 Revised: 05 December 2021 Accepted: 10 January 2022 Publication: 28 February 2022

(4) The principle of combining qualitative and quantitative indicators, simple subjective qualitative indicators or quantitative indicators can not be fully applicable to the evaluation of tourism development potential. For example, when it comes to facilities and service experience, tourists' perception and other indicators, the evaluator's subjective and qualitative scoring is adopted, and the environmental quality, socio-economic conditions and other indicators are collected through official quantitative data and quantitative research methods are adopted. Therefore, we should follow the principle of combining qualitative and quantitative, and explain the evaluation results scientifically and objectively.

Taking the evaluation of the development potential of forest health tourism as the starting point, combined with the principle of index selection, and referring to national standards such as national health tourism demonstration base, quality evaluation of forest health base and quality evaluation of forest health base. Sort out the existing domestic and foreign research results of forest health care and tourism resource evaluation, and fully consider the influencing factors related to the development potential of forest health care tourism by consulting experts and scholars in the fields of management, forestry and geography, based on highlighting the characteristics of the specific tourism industry of "forest health care". Through repeated interviews and screening, a preset index system is formed. On this basis, the Delphi method (expert consultation method) is revised and improved to establish the final evaluation index system of forest health tourism development potential.

\section{STUDY ON EVALUATION MODEL OF FOREST HEALTH TOURISM DEVELOPMENT POTENTIAL}

Analytic hierarchy process (AHP) is a decision-making method that divides complex and fuzzy problems into several levels and factors for qualitative and quantitative analysis. At present, it is a more common and mature method and commonly used to determine the weight.

According to the evaluation index system of forest health tourism development potential, the expert weight consultation questionnaire is designed, and 22 experts participating in the first two rounds of index system questionnaire are invited to score the judgment matrix. The expression form of judgment matrix is shown in Table 1, and the scale meaning and assignment of judgment matrix are shown in Table 2.

TABLE I. Judgment matrix

\begin{tabular}{|c|c|c|c|c|}
\hline $\begin{array}{c}\text { EVALUATION ON } \\
\text { THE } \\
\text { DEVELOPMENT } \\
\text { POTENTIAL OF }\end{array}$ & $\begin{array}{c}\text { HEALTH } \\
\text { RESOURCES }\end{array}$ & $\begin{array}{c}\text { HEALTHY } \\
\text { ENVIRONMENT }\end{array}$ & $\begin{array}{l}\text { HEALTH CARE } \\
\text { FACILITIES } \\
\text { AND SERVICES }\end{array}$ & $\begin{array}{l}\text { DEVELOPMENT } \\
\text { CONDITIONS }\end{array}$ \\
\hline
\end{tabular}


Article History: Received: 28 October 2021 Revised: 05 December 2021 Accepted: 10 January 2022 Publication: 28 February 2022

\begin{tabular}{|c|c|c|c|c|}
\hline $\begin{array}{c}\text { FOREST HEALTH } \\
\text { TOURISM }\end{array}$ & 1 & 3 & $1 / 2$ & $1 / 5$ \\
\hline $\begin{array}{c}\text { HEALTH } \\
\text { RESOURCES }\end{array}$ & 1 & 1 & $1 / 5$ & $1 / 7$ \\
\hline $\begin{array}{c}\text { HEALTHY } \\
\text { ENVIRONMENT }\end{array}$ & $1 / 3$ & 5 & 1 & $1 / 3$ \\
\hline $\begin{array}{c}\text { HEALTH CARE } \\
\text { FACILITIES AND } \\
\text { SERVICES }\end{array}$ & 2 & 7 & 2 & 1 \\
\hline $\begin{array}{c}\text { DEVELOPMENT } \\
\text { CONDITIONS }\end{array}$ & 5 & & \\
\hline
\end{tabular}

TABLE II. Scale description

\begin{tabular}{|c|c|}
\hline SCORE & MEANING \\
\hline 1 & $\begin{array}{c}\text { Indicates that two elements are of equal importance } \\
\text { compared to each other }\end{array}$ \\
\hline 3 & $\begin{array}{c}\text { Indicates that the former is slightly more important } \\
\text { than the latter }\end{array}$ \\
\hline 5 & $\begin{array}{c}\text { Indicates that the former is obviously more important } \\
\text { than the latter }\end{array}$ \\
\hline 7 & $\begin{array}{c}\text { Indicates that the former is more important than the } \\
\text { latter }\end{array}$ \\
\hline 9 & $\begin{array}{c}\text { Indicates that compared with two elements, the former } \\
\text { is extremely important than the latter }\end{array}$ \\
\hline $2,4,6,8$ & $\begin{array}{c}\text { Represents the intermediate value of the above } \\
\text { adjacent judgment }\end{array}$ \\
\hline $\begin{array}{c}\text { IF THE LATTER IS } \\
\text { MORE IMPORTANT } \\
\text { THAN THE FORMER }\end{array}$ & It can be expressed by the reciprocal (e.g. 1/9) \\
\hline
\end{tabular}

Hierarchical single ranking refers to the relative weight value of each element in the judgment matrix for the previous level, which can be transformed into the problem of finding the maximum eigenvalue and eigenvector of the judgment matrix. In this study, the root square method is used for calculation, and the calculation formula of eigenvector is:

$$
W_{i}=\bar{W}_{i} / \sum_{i=1}^{n} \bar{W}_{i}(i=1,2,3 \ldots n)
$$

Of which: 
Article History: Received: 28 October 2021 Revised: 05 December 2021 Accepted: 10 January 2022 Publication: 28 February 2022

$$
\bar{W}_{i}=\sqrt[n]{\prod_{j=1}^{n} q_{i j}}(i=1,2,3 \ldots n)
$$

The calculation formula of maximum characteristic root is:

$$
\bar{W}_{i}=\sqrt[n]{\prod_{j=1}^{n} q_{i j}}(i=1,2,3 \ldots n)
$$

In the comprehensive layer, the weight of health care environment is the largest $(0.4808)$, followed by health care resources (0.2948), and the weight values of health care facilities and services (0.1392) and development conditions (0.0851) are the last. The healthy environment is at the core of forest health tourism, which shows that the forest environment is more conducive to reducing people's pressure, which is in line with the people's inertial thinking about choosing forest health base tourism. In addition, the contribution of health care resources to forest health care tourism can not be underestimated, reflecting that tourism destinations with diverse resource background conditions are more attractive to the public. Scientific supporting facilities and perfect service functions can maximize the advantages of forest health environment and resources. The development condition is the external environment for the development of forest health tourism. Through reasonable planning and development, it can improve the satisfaction of tourists and the happiness of local residents.

In the element layer, the highest index weight is environmental quality (0.3617), followed by resource characteristics $(0.1753)$, resource value $(0.1195)$ and environmental carrying capacity (0.1191). It shows the importance of healthy environment, especially environmental quality, to forest healthy tourism. For forest healthy tourism base, the focus of forest healthy tourism development is the coordination and unity between healthy resources and healthy environment. Among them, the characteristics and resource value of health care resources directly affect the development degree of health care resources. However, if health care facilities and services are not in place, socio-economic conditions are limited, tourist market development is insufficient, location conditions are at a disadvantage, and tourists and residents' perception of health care tourism is weak, it will also lead to the lag of forest health care tourism development.

In the index layer, the forest coverage rate (0.0890), air anion content (0.0685), canopy density (0.0498) and the number of tourists that can be accommodated in the scenic spot (0.0493) have a high weight, indicating that people choose the forest health tourism base, pay more attention to the forest environment of the base and tend to experience better destinations, The carrying capacity of the scenic spot provides guarantee for the development and protection of forest health tourism resources. The scale and abundance of resources (0.0427), the value of sightseeing and Recreation (0.0405) and the weight of health trail (0.0388) are also relatively large, which to some extent reflects the focus and direction of attention in the development of 
Article History: Received: 28 October 2021 Revised: 05 December 2021 Accepted: 10 January 2022 Publication: 28 February 2022

forest health tourism and meets the health needs of forest health tourists.

The evaluation of the development potential of forest health tourism is a means to measure the development and construction of forest health tourism related projects and give priority to the development of forest health tourism. Its fundamental purpose is to promote the sustainable development of the tourism destination in the vertical dimension of the life cycle and the horizontal dimension of Geography through scientific means, and finally realize the unity of economic, social and ecological benefits. Through the comparative study of health care resources, health care environment, health care facilities and services and development conditions, it is concluded that the three cases have the highest score in the comprehensive layer of health care resources, followed by health care environment, and the development conditions have the lowest score. In the actual verification process, tourists scored low on the environmental carrying capacity in the ground element layer of the three cases, resulting in a relatively large weight but a relatively low score of the healthy environment. In view of the above problems, this paper puts forward countermeasures and suggestions for developing forest health tourism at the beginning of the development of forest health base, in order to provide reference for the development of forest health base in all provinces.

(1) Protect the development of forest health tourism resources and create diversified health products. Through the analysis of the survey data of three forest health care bases, it is concluded that how to carry out protective development of forest health care tourism resources has become a key issue to enhance the attraction and appeal of forest health care tourism. We should make full use of the advantages of forest resources in the base, and deeply tap the multiple values of recreational and ornamental resources, landscape aesthetics, health care and culture according to the characteristics of health care resources.

(2) Optimize the health care environment and establish an all-round awareness of ecological health care. Healthy environment is the core of forest healthy tourism. As the root of the development of forest healthy tourism, the government, community residents, enterprises, tourists and other stakeholders should establish an all-round ecological healthy concept while carrying out the protective development of forest resources.

(3) Improve forest health tourism facilities and provide standardized services. Although the proportion of health care facilities and services in the development potential of forest health care tourism is small, its reasonable layout and standardized supporting facilities can bring good health care experience to forest health care tourists. The scientific layout and interesting presentation of the identification, guidance and interpretation system can provide tourists with a way to deeply carry out forest health tourism. Sightseeing platform, yoga platform, forest bathing place and other leisure, entertainment and health care facilities can enhance tourists' sense of experience. Professional forest commentators or health care teachers are also one of the necessary conditions for the forest health care base, which can mobilize the enthusiasm of tourists to participate in the experience of forest health care. At the same time, the base with a 
Article History: Received: 28 October 2021 Revised: 05 December 2021 Accepted: 10 January 2022 Publication: 28 February 2022

quiet and comfortable environment and covering the functions of forest health care catering, accommodation and shopping is more popular with health care tourists.

(4) Improve the development conditions and improve the satisfaction of tourists and residents. The development conditions include the basic guarantee conditions of social economy, market and location conditions. At the same time, the perception of tourists and residents on the base is also the basis to test the development potential of forest health tourism in the base. We should not only train local forest commentators or forest health care teachers, but also strengthen the publicity of public information related to forest health care, so as to cultivate the public's awareness of comprehensive understanding of forest health care and ecological civilization; On the basis of not damaging the ecological environment, residents can be encouraged to actively participate in the development and operation of forest health tourism, broaden their income channels, increase income sources, and promote the promotion of local comprehensive social value.

\section{CONCLUSION}

This paper studies the integrated development of forest health tourism under the background of Rural Revitalization Strategy. In this paper, Delphi method and analytic hierarchy process are used to determine the index weight. In the comprehensive layer, the health care environment has the largest weight, accounting for $48.08 \%$, followed by health care resources and health care facilities and services, accounting for $29.48 \%$ and $13.92 \%$ respectively, and the importance of development conditions is the smallest, accounting for $8.51 \%$. This shows that natural and high-quality healthy environment and healthy resources are the premise of forest healthy tourism development. In the element layer, the weight of environmental quality is the largest, accounting for $36.17 \%$. At the same time, the importance of resource characteristics and resource value is also relatively high, accounting for $17.53 \%$ and $11.95 \%$ respectively. Tourists' perception and residents' perception account for the least, accounting for $1.34 \%$ and $0.59 \%$ respectively, which plays an auxiliary role in the development of forest health tourism. In the index layer, the weight of forest coverage and air anion content is large, which are $8.9 \%$ and $6.85 \%$ respectively. Once again, it emphasizes the importance of healthy environment to the development of forest healthy tourism; Residents' participation in the development and operation of health tourism and the importance of residents' hospitality are relatively small. It accounts for $0.2 \%$ and $0.11 \%$ respectively, but it is also an indispensable condition for the development of forest health tourism. At the same time, the evaluation standard of forest health tourism development potential index is determined, and the practical comprehensive scoring model and evaluation grade are established.

\section{REFERENCES}


Article History: Received: 28 October 2021 Revised: 05 December 2021 Accepted: 10 January 2022 Publication: 28 February 2022

1. Wang Junqi. on the Concept of Folk Sports and the Existing Problems in Research -- Also on the Necessity of Establishing Folk Sports Discipline. Journal of Xi'an Institute of Physical Education, 2007 (02): 16-20

2. Tu Chuanfei, Chen Zhidan, Yan Wei. the Concept and Relationship of Folk Sports, Traditional Sports, Folk Sports and National Sports. Journal of Wuhan Institute of Physical Education, 2007, 41 (8): 24-31

3. Chen Yonghui, Bai Jinxiang. Development of Folk Sports Cultural Resources of Ethnic Minorities in China from the Perspective of Intangible Cultural Heritage Protection. Journal of Wuhan Institute of Physical Education, 2009, 43 (3): 75-80

4. Yang Yehong, Mo Mingzhu. Investigation and Research on Folk Sports in Southern Anhui. Fighting. Martial Arts Science, 2008,191(1):146-156.

5. Wang Jinghao, Zhou Aiguang. the Construction of Body Harmony by Folk Sports. Journal of Wuhan Institute of Physical Education, 2008, 7:2(2):729-734.

6. Guan Duohong. Research on the Development of Folk Sports in Tang and Song Dynasties. Lantai World, 2012, 19 (no. 200): 54-55

7. Liu Xiaoping, Chen Hongxin. Significance and Necessity of Introducing Folk Sports into Rural School Physical Education Classroom. Hubei Sports Science and Technology, 2009, 028 (001): 1-2, 7

8. School of Physical Education and Health Science, Guangxi University for Nationalities. the Construction of Physical Harmony by Folk Sports -- on the Development Logic and Modern Road of Folk Sports. 2008, 10: 113-117

9. Tu Chuanfei. Social Reproduction Mechanism: an Anthropological Interpretation of the Historical Role of Folk Sports. Journal of Tianjin Institute of Physical Education, 2011, 26 (1): 19-23

10. Lin Deqiang, Zhu Jiaxin. Assimilation and Evolution: Taiwan Folk Sports Culture from the Perspective of Cultural Sociology. Journal of Jingdezhen University, 2017, 32 (006): 82-85 